\title{
Epidemics of haemorrhagic cystitis due to influenza A virus
}

\author{
ManiJeH KhakPour BiJan Nik-AkHTAR* \\ Department of Pathobiology, School of Public Health, and \\ *Department of Medicine, Pahlavi Medical School, Tehran University, Tehran
}

\begin{abstract}
Summary
The present communication describes studies on thirtythree patients with haemorrhagic cystitis. The current epidemic variant of influenza type A virus, A/Tehran/ $5 / 75\left(\mathrm{H}_{3} \mathrm{~N}_{2}\right)$ [antigenically similar to $A /$ Port Chalmers/1/73 $\left(\mathrm{H}_{3} \mathrm{~N}_{2}\right)$ ], was recovered from the throats of eighteen and the urine of three patients. HI antibody rises to $\mathrm{A} / \mathrm{Tehran} / \mathbf{5} / 75$ virus were detected in over $\mathbf{5 0} \%$ of the cystitis patients tested.
\end{abstract}

\section{Introduction}

The role of viruses in diseases of the urinary tract and kidneys has been confirmed by many workers (Jensen, 1967; Koszinowski and Volkman, 1974; Burch and Sun, 1968) and it is now apparent that adenoviruses type 11 and 21 can cause haemorrhagic cystitis (Chiba et al., 1974; Numazaki et al., 1973; Mufson and Belshe, 1976). Reports on influenza as an aetiological factor in nephritis have been the matter of much speculation over the past several decades. Thomson and Macauley (1920) reported several cases of nephritis due to influenza some 50 years ago, and Alexander (1965) and Truc, Scillico and Marchal (1951) reported that influenza virus can indeed cause renal pathology.

Viraemia of influenza has been demonstrated on occasions both in man (Khakpour, Saidi and Naficy, 1969; Naficy, 1963; Stanley and Jackson, 1966) and animals (Hamre, Appel and Berlin, 1969) and influenza virus antigen has also been demonstrated in the kidneys (Ishida, Morizuka and Hinuma, 1964).

Because of the rarity of urinary tract involvement in influenza and in spite of some bulk of evidence in the literature, less attention has been paid to the fact that urinary involvement exists in some patients affected with influenza.

In recent epidemics of influenza in Tehran, Iran, many cases of haemorrhagic cystitis were reported and influenza virus was isolated from the urine and throat in some cases, meanwhile the antibody to influenza was raised concomitantly, as measured at the time, and after 6-8 weeks from the onset of the disease.

\section{Materials and methods}

\section{Patient population}

During an epidemic of influenza which lasted from February to April 1975 in Tehran, many affected individuals were reported with signs and symptoms of haemorrhagic cystitis: fever, general malaise, dysuria, increased frequency of urination and haematuria. The symptoms occurred with no immediate cause, haematuria was macroscopic and lasted for 3-5 days and then subsided immediately leaving no symptoms, and all patients recovered spontaneously.

The number of patients involved in the study was thirty-three of which twenty-seven were female and six were male, ranging in age from 14 to 39 years.

\section{Specimens}

Serum samples, throat wash and urine were obtained from all subjects on the first or second day of the onset of cystitis. The second serum samples were taken 6-8 weeks later. All sera were stored at $-20^{\circ} \mathrm{C}$, before using for serological tests. Throat wash and urine were either inoculated within a few hours of collection or stored at $-70^{\circ} \mathrm{C}$ before inoculation.

\section{Viral isolation}

Each throat and urine specimen was inoculated in a volume of $0.2 \mathrm{ml}$ into the amniotic cavity of 10 day-old embryonated eggs and amniotic fluids were harvested after $40 \mathrm{hr}$ incubation at $35^{\circ} \mathrm{C}$ and overnight at $41^{\circ} \mathrm{C}$. All amniotic fluids were tested for haemagglutination (HA) activity. HA-positive fluids were inoculated again but allantoically and HAnegative fluids were passaged once more amniotically. In the second passage, all HA-negative fluids were accounted as virus-free or negative and discarded.

\section{Serological tests}

Haemagglutination inhibition (HI) test was carried out according to the standard technique using one of the new isolated influenza viruses designated as A/Tehran/5/75.

Diagnostic cystoscopy was suggested to all affected individuals and seven of the thirty-three patients 
TABLE 1. Results of HI antibody determination and urinalysis in patients with positive viral isolation

\begin{tabular}{|c|c|c|c|c|c|c|c|c|c|c|}
\hline \multicolumn{3}{|c|}{ Patients } & \multicolumn{2}{|c|}{ Viral isolation } & \multicolumn{2}{|c|}{ Antibody titre* } & \multicolumn{4}{|c|}{ Urinalysis } \\
\hline No. & Sex & $\begin{array}{c}\text { Age } \\
\text { (years) }\end{array}$ & Throat & Urine & Acute & Convalescent & Culture & & $\begin{array}{l}\text { Red blood } \\
\text { cells }\end{array}$ & Protein \\
\hline 1 & $\mathrm{~F}$ & 19 & + & - & $\leqslant 1: 20$ & $1: 640$ & 0 & & Many & Trace \\
\hline 2 & $\mathrm{~F}$ & 21 & + & - & $1: 40$ & $1: 80$ & 0 & & Many & - \\
\hline 3 & $\mathrm{~F}$ & 20 & + & + & $1: 40$ & $1: 1280$ & 0 & & Many & - \\
\hline 4 & F & 32 & + & - & $\leqslant 1: 20$ & $1: 80$ & Escherichia col & $i<5000$ & $20-30$ & - \\
\hline 5 & $\mathbf{M}$ & 27 & + & - & $1: 640$ & $1: 640$ & 0 & & Many & +1 \\
\hline 6 & $\mathrm{~F}$ & 18 & + & - & $1: 80$ & $1: 160$ & 0 & & Many & - \\
\hline 7 & $\mathrm{~F}$ & 16 & + & + & $1: 40$ & $1: 2560$ & 0 & & $15-25$ & - \\
\hline 8 & $\mathbf{M}$ & 31 & + & - & $1: 160$ & $1: 320$ & $\mathbf{0}$ & & Many & - \\
\hline 9 & $\mathbf{M}$ & 34 & + & - & $1: 80$ & $1: 1280$ & Staphylococcus & $<8500 \dagger$ & Many & - \\
\hline 10 & $\mathbf{F}$ & 22 & + & - & $\leqslant 1: 20$ & $1: 40$ & 0 & & Many & Trace \\
\hline 11 & $\mathrm{~F}$ & 21 & + & - & $1: 80$ & $1: 2560$ & 0 & & Many & - \\
\hline 12 & $\mathrm{~F}$ & 25 & + & - & $\leqslant 1: 20$ & $1: 40$ & 0 & & $50-60$ & - \\
\hline 13 & $\mathrm{~F}$ & 25 & + & - & $1: 40$ & $1: 160$ & 0 & & Many & - \\
\hline 14 & $\mathrm{~F}$ & 24 & + & - & $\leqslant 1: 20$ & $1: 640$ & $\mathbf{0}$ & & Many & - \\
\hline 15 & $\mathrm{~F}$ & 20 & + & - & $1: 80$ & $1: 1280$ & 0 & & Many & - \\
\hline 16 & $\mathbf{M}$ & 29 & + & - & $\leqslant 1: 20$ & $1: 1280$ & 0 & & Many & - \\
\hline 17 & $\mathrm{~F}$ & 27 & + & - & $1: 80$ & $1: 160$ & 0 & & Many & - \\
\hline 18 & $\mathrm{~F}$ & 29 & + & + & $\leqslant 1: 20$ & $1: 640$ & 0 & & Many & - \\
\hline
\end{tabular}

* HI antibody titre to $\mathrm{A} / \mathrm{Tehran} / 5 / 75$ virus; $\uparrow$ Staphylococcus coagulase positive.

TABLE 2. Results of $\mathrm{HI}$ antibody determination and urinalysis in patients with negative viral isolation

\begin{tabular}{|c|c|c|c|c|c|c|c|}
\hline \multicolumn{3}{|c|}{ Patients } & \multicolumn{2}{|c|}{ Antibody titre* } & \multicolumn{3}{|c|}{ Urinalysis } \\
\hline No. & Sex & $\begin{array}{c}\text { Age } \\
\text { (years) }\end{array}$ & Acute & Convalescent & Culture & $\begin{array}{l}\text { Red blood } \\
\text { cell }\end{array}$ & Protein \\
\hline 1 & $\mathbf{F}$ & 17 & $\leqslant 1: 20$ & $1: 80$ & 0 & Many & - \\
\hline 2 & $\mathrm{~F}$ & 19 & $\leqslant 1: 20$ & $1: 1280$ & 0 & Many & - \\
\hline 3 & $\mathrm{~F}$ & 24 & $1: 160$ & $1: 80$ & 0 & Many & - \\
\hline 4 & $\mathbf{F}$ & 21 & $1: 40$ & $1: 2560$ & Escherichia coli $<900$ & Many & - \\
\hline 5 & $\mathbf{M}$ & 20 & $1: 160$ & $1: 320$ & 0 & Many & Trace \\
\hline 6 & $\mathbf{M}$ & 26 & $\leqslant 1: 20$ & $1: 160$ & 0 & Many & — \\
\hline 7 & $\mathbf{F}$ & 28 & $1: 640$ & $1: 640$ & 0 & Many & - \\
\hline 8 & $\mathbf{F}$ & 27 & $1: 20$ & $1: 40$ & 0 & Many & - \\
\hline 9 & $\mathbf{F}$ & 35 & $1: 1280$ & $1: 640$ & $\mathbf{0}$ & Many & - \\
\hline 10 & $\mathbf{F}$ & 39 & $1: 40$ & $1: 160$ & 0 & $20-40$ & - \\
\hline 11 & $\mathbf{F}$ & 23 & $1: 80$ & $1: 640$ & 0 & Many & - \\
\hline 12 & $\mathbf{F}$ & 34 & $\leqslant 1: 20$ & $1: 80$ & 0 & Many & - \\
\hline 13 & $\mathbf{F}$ & 30 & $\leqslant 1: 20$ & $1: 40$ & E. coli $<7300$ & Many & Trace \\
\hline 14 & $\mathbf{F}$ & 21 & $1: 40$ & $1: 320$ & 0 & Many & - \\
\hline 15 & $\mathbf{F}$ & 14 & $\leqslant 1: 20$ & $1: 640$ & 0 & Many & - \\
\hline
\end{tabular}

* HI antibody titre to $\mathrm{A} / \mathrm{Tehran} / 5 / 75$ virus.

accepted the procedure. On cystoscopy, the bladder was uniformly congested and haemorrhagic. No ulcer, polyp or other pathology was found. Intravenous pyelography (IVP) was performed in all and reported normal. Urine cultures for bacteriological studies remained negative during the course of the disease, except in four cases (Tables 1 and 2).

\section{Results}

Influenza virus was recovered from eighteen throat wash and three urine samples. Antigenic characteristics of new isolated virus from throat specimens was found to be influenza type $A$ and closely related to the $\mathrm{A} /$ Port Chalmers/1/73. This antigenic characteristic was confirmed by WHO, World Influenza Centre, London.

$\mathrm{HI}$ antibody determination in paired sera revealed a great rise of antibody titre in most of the patients.

Tables 1 and 2 summarize these results from patients with positive and negative viral isolation.

\section{Discussion}

With the advent of laboratory procedures, it is now possible to recover viruses from the urine in certain diseases in which viraemia is present (Jensen, 1967; Zakstel'skaya, 1953; Smith and Aqino, 1971). Affection of the kidneys and urinary tract in viral diseases is also thought to result from the shedding 
of viruses from kidney cells involved in generalized infection. In many instances, viruria will remain harmless and not significant clinically, but in some instances, in certain virurias, this can cause symptoms related to the affected parts of the urinary tract (Smith and Aqino, 1971). Haemorrhagic cystitis due to adenovirus II is a well established entity and viruria has been documented in such instances (Chiba et al., 1974; Myking and Schreiner, 1974).

Recovery of influenza virus from patients' blood was reported only by a few workers (Khakpour et al., 1969; Naficy, 1963; Stanley and Jackson, 1966) and in spite of the fact that renal pathology due to influenza has been reported on several occasions (Thomson and Macauley, 1920; Alexander, 1965; Truc et al., 1951; Myking and Schreiner, 1974; Wilson and Smith, 1972), only in rare instances was virus isolated from the urine of affected individuals (Zakstel'skaya, 1953). The authors recovered influenza virus in the urine of three of thirty-three cases reported to their medical clinic with signs and symptoms of haemorrhagic cystitis. The cystitis lasted 2-5 days with manifestations of dysuria, frequency in micturition and haematuria. The correlation of increased antibody titre from the first day of the illness and 6-8 weeks later was carefully documented in most of the cases and increased titre was noted in these individuals, confirming the fact that although influenza virus could not be recovered in the urine of some patients, haemorrhagic cystitis was directly related to influenza infection as a part of its systemic and urinary tract involvement.

\section{Acknowledgments}

The authors wish to thank Dr G. C. Schild, Head of the Division of Viral Products, National Institute for Biological Standards and Control, London, and previous Director of the WHO World Influenza Centre, Mill Hill, London, for his help in confirming the antigenic characteristics of our isolates.

This study was partially supported by the funds of the Public Health Research Project of the Iranian Ministry of Health and the Plan Organization.

\section{References}

AleXANDer, E.A. (1965) Recurrent hemorrhagic nephritis with exacerbation related to influenza A. Annals of Internal Medicine, 62, 1022.
Burch, G.E. \& Sun, S.C. (1968) Viral nephritis. American Heart Journal, 75, 1.

Chiba, S., Nakao, T., Moria, T. \& Abe, S. (1974) Acute hemorrhagic cystitis due to Adenovirus type II. New England Journal of Medicine, 290, 632.

Hamre, D., Appel, D. \& Berlin, B.S. (1969) Viremia in mice with pulmonary influenza A virus infection. Journal of Laboratory and Clinical Medicine, 47, 182.

Ishida, N., Morizuka, T. \& Hinuma, Y. (1964) Virus antigens in kidneys of mice infected with influenza $A$. Nature. London, 201, 421.

Jensen, M.M. (1967) Viruses and kidney disease. American Journal of Medicine, 43, 897.

Khakpour, M., Saidi, A. \& Naficy, K. (1969) Proved viraemia in Asian influenza (Hong Kong variant) during incubation period. British Medical Journal, 4, 208.

Koszinowski, U. \& Volkman, B. (1974) Virus infection of the urinary tract. Lancet, $\mathbf{i}, 507$.

Mufson, M.A. \& Belshe, R.B. (1976) A review of adenoviruses in the etiology of acute hemorrhagic cystitits. Journal of Urology, 115 (2), 191.

Myking, O. \& Schreiner, A. (1974) Influenza virus infection complicated by severe renal failure. Scandinavian Journal of Infectious Diseases, 6, 205.

Naficy, K. (1963) Human influenza infection with proved viremia; report of a case. New England Journal of Medicine, 269, 964.

Numazaki, Y., Kumasaka, T., Yano, M., Yamanaka, M., MYaZAWA, T., TAKaI, S. \& Ishida, N. (1973) Further study on acute hemorrhagic cystitits due to adenovirus type II. New England Journal of Medicine, 289, 344.

Smith, R.D. \& AQINo, J. (1971) Viruses and the kidney: symposium on diseases of the kidney. Medical Clinics of North America, 55, 89.

Stanley, E.D. \& JACKson, G.G. (1966) Viremia in Asian influenza. Transactions of the Association of American Physicians, 70, 376.

Thomson, W. \& Macauley, H.F. (1920) Influenza as an aetiological factor in nephritis, with an account of four cases of post influenza nephritis in some families. Lancet, i, 481.

Truc, E. Scillico, R. \& Marchal, G. (1951) A propos de quelques cas d'oligo-anurie par néphrite post-grippale. Journal d'urologie médicale et chirurgicale, 57, 734.

WiLson, C.B. \& SMITH, R.C. (1972) Goodpasture's syndrome associated with influenza A/2 virus infection. Annals of Internal Medicine, 76, 91.

ZAKSTEL'SKAYA, L.Y. (1953) Gripp i ostrye katarry verkhnikh dykhatel'nykh putei. [Recovery of virus from urine of patients with epidemic influenza.] Trudy ob'vedinnenykh sessyi Instituta Academiia Meditsinskikh nauk SSSR, p. 72. 